\title{
PENGARUH KONTRASEPSI SUNTIK 3 BULAN TERHADAP KENAIKAN BERAT BADAN IBU DI PUSKESMAS GEDONG AIR KOTA BANDAR LAMPUNG TAHUN 2020
}

\author{
Devi Kurniasari $^{1}$, Susilawati ${ }^{1}$, Nabela Gyandra Fenniokha ${ }^{2}$ \\ ${ }^{1}$ Dosen Program Studi D IV Kebidanan Universitas Malahayati \\ 2Program Studi Kebidanan Universitas Malahayati
}

[email korespondensi: nabelagf10@gmail.com]

\begin{abstract}
The Effect Of 3-Month Injectable Contraception On Maternal Weight Gain At Gedong Air Health Center, Bandar Lampung City In 2020. The contraception that is mostly chosen by acceptors in Indonesia is $61.4 \%$ injectable contraception, but injection contraception has an impact that can cause weight gain. acceptors revealed that by using injectable contraception they felt it was more practical in the family planning process. The purpose of the study was to find the effect of 3-month injection contraception on maternal weight gain in Puskesmas Gedong Air Bandar Lampung in 2020. This type of quantitative research, analytical research design with true experiment approach with two group posttest only design with control group design population in this study were all 804 family planning ask-receptors, 40 samples divided into 2 groups, simple random sampling technique, this research was conducted in July 2020. data collection using observation sheets. Univariate and bivariate data analysis t-test (t-test). The results showed that the mean increase in body weight for 3 months injection family planning acceptors was $3,7 \mathrm{~kg}$, the mean increase in body weight for 1 month injection family planning acceptors was $1,8 \mathrm{~kg}$. There is no effect of 3-month injection contraception on maternal weight gain at the Gedong Air Bandar Lampung Community Health Center in 2020, the statistical test results obtained pvalue $=0.016(p$-value $>a=0.05)$. Health workers are expected to be able to provide counseling for hormonal contraceptive acceptors, especially injections to be able to switch to long-term non hormonal contraceptives such as IUDs.
\end{abstract}

Key words: Contraception, 3 Months Injection, Body Weight

\begin{abstract}
Abstrak: Pengaruh Kontrasepsi Suntik 3 Bulan Terhadap Kenaikan Berat Badan Ibu Di Puskesmas Gedong Air Kota Bandar Lampung Tahun 2020. Kontrasepsi yang banyak dipilih oleh akseptor di Indonesia adalah kontrasepsi suntik sebanyak 61,4\%, namun kontrasepsi suntik memiliki dampak yang dapat menyebabkan penambahan berat badan. akseptor mengungkapkan dengan menggunakan kontrasepsi suntik mereka merasa lebih praktis dalam proses KB.tujuan penelitian Diketahui Pengaruh Kontrasepsi Suntik 3 Bulan Terhadap Kenaikan Berat Badan Ibu Di Puskesmas Gedong Air Bandar Lampung Tahun 2020.Jenis penelitian kuantitatif, desain penelitian analitik dengan pendekatan true eksperimen dengan rancangan two group posttest only with Control group design populasi dalam penelitian ini adalah seluruh akseptor KB sebanyak 804, sampel sebanyak 40 yang dibagi 2 kelompok, teknik sampling secara simple random sampling, penelitian ini telah dilakukan bulan Juli 2020. pengumpulan data dengan lembar observasi. Analisa data univariat dan bivariat uji $t$ ( $t$-test). Hasil penelitian Diketahui mean peningkatan berat badan akseptor KB Suntik 3 bulan seberat $3,7 \mathrm{Kg}$, mean peningkatan berat badan akseptor KB Suntik 1 bulan seberat $1,8 \mathrm{Kg}$. Tidak ada Pengaruh Kontrasepsi Suntik 3 Bulan Terhadap Kenaikan Berat Badan Ibu Di Puskesmas Gedong Air Bandar
\end{abstract}


Lampung Tahun 2020, hasil uji statistik didapatkan $p$-value $=0,016$ ( $p$-value $>a=$ $0,05)$. tenaga kesehatan diharapkan dapat memberikan konseling pada akseptor kontrasepsi hormonal khususnya suntik untuk bisa beralih kekontrasepsi nonhormonal jangka panjang seperti IUD.

Kata kunci: Kontrasepsi, Suntik 3 Bulan , Berat Badan

\section{PENDAHULUAN}

Keluarga mempunyai arti penting dalam kehidupan di masyarakat. Terbentuknya keluarga bukan sematamata mempunyai kepentingan yang sama, namun lebih dari itu adalah berdasarkan sukarela dan cinta kasih yang mendalam di antara dua manusia. Terbentuknya keluarga bertujuan untuk terciptanya sebuah keluarga sakinah, mawaddah warahmah (dilihat dari perspektif Islam) (BKKBN, 2017).

Peraturan Pemerintah Republik Indonesia Nomor 87 Tahun 2014 tentang Perkembangan Kependudukan dan Pembangunan Keluarga, Keluarga Berencana dan Sistem Informasi Keluarga menyebutkan bahwa program keluarga berencana (KB) adalah upaya mengatur kelahiran anak, jarak dan usia ideal melahirkan, mengatur kehamilan, melalui promosi, perlindungan, dan bantuan sesuai dengan hak reproduksi untuk mewujudkan keluarga yang berkualitas. Dalam pelaksanaannya, sasaran pelaksanaan program KB yaitu Pasangan Usia Subur (PUS). Pasangan Usia Subur (PUS) adalah pasangan suami-istri yang terikat dalam perkawinan yang sah, yang istrinya berumur antara 15 sampai dengan 49 tahun (Kemenkes, 2017).

Jumlah perempuan di negaranegara termiskin di dunia yang menggunakan kontrasepsi modern telah melonjak lebih dari 30 juta dalam empat tahun terakhir, menurut sebuah laporan yang menemukan kemajuan paling signifikan telah dicapai di sub-Sahara Afrika. Sekitar 12 juta lebih perempuan dan anak perempuan menggunakan alat kontrasepsi di timur, selatan dan barat Afrika. Negara-negara termasuk Ethiopia, Kenya, Lesotho, Malawi dan
Mozambik. Secara riil, untuk Kenya, itu berarti 1,15 juta wanita tambahan yang menggunakan alat kontrasepsi. Di Ethiopia, jumlahnya 1,98 juta. Untuk pertama kalinya, lebih dari $30 \%$ wanita dan anak perempuan di Afrika timur dan selatan menggunakan beberapa bentuk metode kontrasepsi modern. Di Afrika barat mencapai 1 juta pengguna tambahan antara tahun 2011 dan 2015. Sejak tahun 2012, hampir 7,7 juta lebih wanita di India sekarang menggunakan alat kontrasepsi, sementara Afghanistan telah menambahkan 296.000 (Rilyani, 2018).

Peserta program KB secara nasional tahun 2015 mencapai 32 juta akseptor yang terdiri dari sebanyak 28 juta akseptor aktif dan 4 juta akseptor baru (BKKBN, 2017). Dengan penggunaan KB suntik sebesar $47,96 \%$, KB Pil sebesar $22,81 \%$ kontrasepsi implant sebesar $11,20 \%$. Persentase peserta KB aktif terhadap pasangan usia subur di Indonesia pada tahun 2016 sebesar $74,8 \%$. Tiga provinsi yang memiliki persentase tertinggi yaitu Maluku Utara sebesar 87,03\%, Kepulauan Bangka Belitung sebesar 83,92\%, dan Sulawesi Utara sebesar 83,84\%. Sedangkan capaian terendah terdapat di Provinsi Nusa Tenggara Timur sebesar 63,24\%, Sumatera Barat sebesar $63,73 \%$, dan DKI Jakarta sebesar $67,46 \%$. Sedangkan Provinsi Lampung sebesar $71,93 \%$ masih di bawah target Indonesia (Kemenkes, 2017).

Data $61,4 \%$ warga Indonesia yang menggunakan kontrasepsi yang memilih kontrasepsi suntik. Ada dua jenis pilihan kontrasepsi yaitu kontrasepsi suntik 1 bulan Noristerat diberikan 200 mg, kontrasepsi suntik 3 bulan Depo provera 
$150 \mathrm{mg}$ dan Depo progestin $150 \mathrm{mg}$ diberikan 3 bulan sekali. Berdasarkan jenis kontrasepsi suntik efek kontrasepsi DMPA menyebabkan penambahan berat badan karena DMPA merangsang pusat pengendali nafsu makan di hipotalamus yang menyebabkan akseptor makan lebih banyak dari biasanya (Sumantri, 2018)

Cakupan Peserta KB aktif di Provinsi Lampung tahun 2015 sebesar71,14\% meningkat bila dibandingkan tahun sebelumnya, telah mencapai targetsebesar 70\% (Dinkes Provinsi Lampung, 2016) dan di tahun 2016 masih dibawah target Nasional yaitu sebesar 71,93\% (Kemenkes, 2017). Bila dilihat berdasarkan distribusi kabupaten kota tahun 2015 maka Kabupaten Kota yang pencapaiannya lebih dari 71,14\%, yaitu Kabupaten Pringsewu, Mesuji, Pesisir Barat, Metro, Tanggamus dan Lampung Barat sedangkan Kota Bandar Lampung masih dibawah target yaitu sebesar $70,67 \%$ (Dinkes Provinsi Lampung, 2016).

Cakupan peserta kontrasepsi di Puskesmas Gedong Air tahun 2018 dari 7.087 pasangan usia subur (PUS) jumlah peserta KB aktif sebesar 5.218 dan yang menggunakan kontrasepsi suntik sebesar 777 (14,9\%) akseptor. Pada tahun 2019 dari 7.080 PUS, jumlah peserta KB sebesar 5289 dan yang menggunakan kontrasepsi suntik sebanyak $804(15,2 \%)$ akseptor (Data Puskesmas Gedong Air, 2020).

$$
\text { Umumnya penambahan berat }
$$

badan bervariasi kurang dari $1 \mathrm{~kg}$ sampai $5 \mathrm{~kg}$ dalam tahun pertama pemakaian (Hartanto, 2004). Semua alat kontrasepsi pasti ada keuntungan dan ada kerugiannya, begitu juga kontrasepsi suntik. Kontrasepsi suntik juga memiliki dampak baik dan dampak buruk bagi pengguna. Menurut Saifuddin (2014) dampak baiknya antara lain kontrasepsi suntik memiliki tingkat efektivitas tinggi dalam pencegahan kehamilan jangka panjang. Kontrasepsi suntik juga tidak berpengaruh pada hubungan suami-istri.
Kontrasepsi suntik tidak mengandung estrogen sehingga tidak berdampak serius terhadap penyakit jantung, gangguan pembekuan darah, mencegah kanker endometrium dan kehamilan ektopik, menurunkan kejadian penyakit kanker payudara, mencegah beberapa penyebab penyakit radang panggul, menurunkan krisis anemia bulan sabit, dan tidak berpengaruh terhadap ASI karena kontrasepsi 3 bulan hanya mengandung progestin, sedikit efek samping.

Sebagai alat kontrasepsi, kontrasepsi suntik mempunyai keuntungan dan efek samping. Efek samping tersebut diantaranya perubahan pola menstruasi. Secara teori akseptor kontrasepsi suntik 1 bulan dapat mengalami pola menstruasi yang normal dan sebagian dapat mengalami perubahan pola menstruasi. Akseptor kontrasepsi suntik 3 bulan dapat mengalami gangguan pola menstruasi, seperti siklus haid yang memendek atau memanjang, perdarahan yang banyak atau sedikit, perdarahan tidak teratur atau perdarahan bercak bahkan tidak menstruasi sama sekali (amenorhoe) (Saifudin, 2014).

Ibu tidak perlu menyimpan obat suntik dan juga dapat digunakan oleh perempuan usia lebih 35 tahun sampai perimenopause. Dampak dari KB suntik adalah perdarahan tidak teratur atau perdarahan bercak atau amenorhea, keterlambatan kembali subur sampai satu tahun, emosi sering tidak stabil, sakit kepala, kembung, depresi dan peningkatan berat badan. Efek samping dari kontrasepsi hormonal salah satunya yaitu peningkatan berat badan. Peningkatan berat badan disebabkan oleh hormon progesteron yang merangsang hipotalamus lateral menyebabkan perubahan karbohidrat dan gula menjadi lemak, sehingga lemak dalam tubuh akan menjadi banyak dan terjadilah peningkatan berat badan(Affandi, 2012). 
Dampak penggunaan DMPA Efek samping yang ditemukan pada kontrasepsi suntik adalah perubahan berat badan, gangguan haid, depresi, keputihan, jerawat dan sebagainya. Gangguan pola haid yang terjadi tergantung pada lama pemakaian. Gangguan pola haid yang dimaksud seperti perdarahan bercak atau flek, perdarahan irregular, amenore dan perubahan dalam frekuensi, lama dan jumlah darah yang hilang dan pada penggunaan kontrasepsi suntik, endometrium menjadi dangkal dan atropis dengan kelenjar-kelenjar yang tidak aktif dan insidens yang tinggi dari amenorhoe diduga berhubungan dengan atrofi endometrium (Rahayu, 2017).

Kontrasepsi suntik 3 bulan lebih mempengaruhi pada peningkatan berat badan karena DMPA merangsang pusat pengendalian nafsu makan hipothalamus merangsang pusat pengendalian nafsu makan di hipotalamus yang dapat menyebabkan akseptor makan lebih banyak dari biasanya, sehingga berpotensi mengalami peningkatan berat badan. Kenaikan BB, disebabkan karena hormon progesteron mempermudah perubahan karbohidrat dan gula menjadi lemak, sehingga lemak di bawah kulit bertambah, selain itu hormon progesteron juga menyebabkan nafsu makan bertambah dan menurunkan aktivitas fisik, akibatnya pemakaian suntikan dapat menyebabkan BB bertambah (Sumantri, 2018).

Panjaitan (2017) menyatakan bahwa umumnya efek samping utama pemakaian DMPA adalah kenaikan berat badan.sebuah penelitian melaporkan peningkatan berat badan lebih dari 2 kilogram pada tahun pertama dan selanjutnya meningkat secara bertahap hingga mencapai 7,5 kilogram. Sedangkan pemakaian cyclofem berat badan meningkat rata-rata 2-3 kilogram tahun pertama pemakaian dan terus bertambah selama tahun kedua.

Peningkatan berat badan yaitu meningkatkan berat badan ibu selama menggunakan alat kontrasepsi hormonal dimana peningkatan yang sering terjadi antara 1 - $2 \mathrm{~kg}$. Apabila peningkatan berat badan akseptor melebihi dari berat badan normal selama menggunakan alat kontrasepsi hormonal, maka diperlukan penelitian lebih lanjut (Affandi, 2012).

Berdasarkan penelitian, wanita yang menggunakan kontrasepsi DMPA atau dikenal KB suntik tiga bulan, ratarata mengalami peningkatan berat badan sebanyak 11 pon atau $5,5 \mathrm{~kg}$ dan mengalami peningkatan lemak tubuh sebanyak 3,4\% dalam waktu tiga tahun pemakaian. Sedangkan pada kontrasepsi suntik bulanan efek samping terhadap pertambahan berat badan sedikit (Roza, 2017).

Sebagian besar pengguna DMPA akan mengalami peningkatan berat badan sebesar $5 \%$ dalam 6 bulan pertama. Penelitian Berenson dan Rahman pada tahun 2009 menyimpulkan bahwa selama 36 bulan, pengguna DMPA mengalami peningkatan berat badan sebanyak $5.1 \mathrm{~kg}$, lemak tubuh $4.1 \mathrm{~kg}$, dan persentase lemak tubuh $3.4 \%$, sedangkan penggunaan kontrasepsi suntik 3 bulan pada wanita dewasa terbukti signifikan meningkatkan berat badan, setelah penggunaan lebih dari 6 bulan yaitu terjadi peningkatan berat badan sebesar lebih dari 5\% (Pratiwi, 2014).

Penelitian Pratiwi (2014) Analisis data dilakukan secara bivariat dengan menggunakan uji $\mathrm{T}$. Hasil penelitian menunjukkan 23 akseptor (57.50\%) mengalami peningkatan berat badan. Sebagian besar rata-rata peningkatan berat badan dalam satu tahun adalah $>0$ - $1 \mathrm{~kg}$ (47.8\% akseptor). Rata-rata berat badan sebelum dan setelah penggunaan kontrasepsi DMPA adalah $54.4 \mathrm{~kg}$ dan $58.1 \mathrm{~kg}$. Terdapat hubungan yang bermakna antara penggunaan kontrasepsi hormonal suntik DMPA dengan peningkatan berat badan $(p=0.000<0.05)$.

Berdasarkan data awal yang didapatkan di Puskesmas Gedong Air 
Bandar Lampung, didapatkan jumlah akseptor KB dari bulan JanuariDesember 2019 sebanyak 446 akseptor. Metode kontrasepsi yang terbanyak digunakan adalah suntikan 3 bulan sebanyak 219 akseptor, Suntik 1 bulan 103, Pil sebanyak 83 akseptor, Implant sebanyak 29 akseptor, dan IUD sebanyak 12 akseptor. Pada data tersebut terlihat kenaikan berat badan pada suntikan 3 bulan terdapat 61 ibu dengan kenaikan berat badan selama 1 tahun, pada akseptor KB implan terlihat 6 ibu dengan kenaikan berat badan selama 1 tahun $1-2 \mathrm{~kg}$ (Puskesmas Gedong Air Bandar Lampung, 2020).

Berdasarkan hasil survey yang dilakukan pada tanggal 3-5 Maret 2020 terhadap 20 akseptor KB, sebanyak 16 orang menggunakan kontrasepsi suntik dan 4 orang menggunakan kontrasepsi pil. Pada pengguna kontrasepsi PIL, seluruhnya tidak mengalami peningkatan berat badan namun terdapat 1 (25\%) akseptor mengeluhkan sering sakit kepala. Pada 16 akseptor KB suntik sebanyak $13(81.2 \%)$ orang mengatakan mengalami peningkatan berat badan 1-2

\section{Analisis Univariat}

Tabel 1. Peningkatan berat badan akseptor KB Suntik 3 Bulan dan 1 bulan Di Puskesmas Gedong Air Bandar Lampung Tahun 2020

\begin{tabular}{cccc}
\hline Peningkatan berat badan & N & Mean & Minimal \\
\hline sesudah 3 bulan & 20 & 3,70 & 0,00 \\
sesudah 1 bulan & 20 & 1,80 & 0,00 \\
\hline
\end{tabular}

Berdasarkan tabel diatas diketahui mean peningkatan berat badan akseptor KB Suntik 3 bulan sebesar $3,70 \mathrm{Kg}$ dengan peningkatan berat badan minimal $0,00 \mathrm{Kg}$ dan maximal $9,00 \mathrm{Kg}$. $\mathrm{kg}$ selama menggunakan KB suntik sedangkan $3 \quad(18.7 \%)$ akseptor mengatakan tidak mengalami peningkatan berat badan. Dari 16 akseptor KB suntik, hampir semua akseptor mengungkapkan dengan menggunakan kontrasepsi suntik mereka merasa lebih praktis dalam proses KB.

Berdasarkan hal tersebut, maka penulis tertarik untuk meneliti bagaimana Pengaruh Kontrasepsi Suntik 3 Bulan Terhadap Kenaikan Berat Badan Ibu Di Puskesmas Gedong Air Bandar Lampung Tahun 2020.

\section{METODE}

Jenis penelitian kuantitatif, desain penelitian analitik dengan pendekatan true eksperimen dengan rancangan two group postest only With Control group design yang meneliti tentang Pengaruh Kontrasepsi Suntik 3 Bulan Terhadap Kenaikan Berat Badan Ibu Di Puskesmas Gedong Air Bandar Lampung Tahun 2020 populasi dalam penelitian ini adalah seluruh wanita usia subur, penelitian ini telah di lakukan bulan Juli 2020.

\section{Analisis Bivariat}

Tabel 2. Pengaruh Kontrasepsi Suntik 3 Bulan Terhadap Kenaikan Berat Badan Ibu Di Puskesmas Gedong Air Bandar Lampung Tahun 2020

\begin{tabular}{rcccc}
\hline kontrasepsi & Mean & Beda Mean & SE & P-Value \\
\hline suntik 3 bulan & 3,7000 & 1,90 &, 75 & 0,016 \\
suntik 1 bulan & 1,8000 & & & \\
\hline
\end{tabular}


Berdasarkan tabel diatas Distribusi rerata Kenaikan Berat Badan Ibu suntik 3 bulan sebesar 3,70 $\mathrm{Kg}$ dan rata-rata berat badan akseptor KB suntik 1 bulan seberat $1,80 \mathrm{Kg}$, hasil uji statistik

\section{PEMBAHASAN \\ KB Suntik}

Berdasarkan hasil penelitian diketahui mean peningkatan berat badan akseptor KB Suntik 3 bulan sebesar 3,70 $\mathrm{Kg}$ dengan peningkatan berat badan minimal 0,00 Kgdan maximal 9,00 Kg dan dari penelitian juga diketahui mean peningkatan berat badan akseptor KB Suntik 1 bulan seberat $1,80 \mathrm{Kg}$ dengan peningkatan berat badan minimal 0,00 $\mathrm{Kg}$ dan maximal 9,00 $\mathrm{Kg}$.

$$
\text { Sebagai alat kontrasepsi, }
$$

kontrasepsi suntik mempunyai keuntungan dan efek samping. Efek samping tersebut diantaranya perubahan pola menstruasi. Secara teori akseptor kontrasepsi suntik 1 bulan dapat mengalami pola menstruasi yang normal dan sebagian dapat mengalami perubahan pola menstruasi. Akseptor kontrasepsi suntik 3 bulan dapat mengalami gangguan pola menstruasi, seperti siklus haid yang memendek atau memanjang, perdarahan yang banyak atau sedikit, perdarahan tidak teratur atau perdarahan bercak bahkan tidak menstruasi sama sekali (amenorhoe) (Saifudin, 2014).

Salah satu tujuan utama dari kontrasepsi ini adalah untuk mengembangkan suatu metode kontrasepsi yang berdaya kerja panjang (lama) yang tidak membutuhkan pemakaian setiap hari akan bersenggama, tetapi tetap reversible (Manuaba, 2014). Kontrasepsi suntik depo provera yang mengandung Depo Medroxyprogesterone Acetate(DMPA) $150 \mathrm{mg}$ yang hanya berisi hormone progesterone dan tidak mengandung esterogen. Daya kerja kontrasepsi DMPA ini adalah $150 \mathrm{mg}$ setiap 3 bulan dan merupakan dosis yang tinggi.Setelah didapatkan $p$-value $=0,016(<\mathrm{a} 0,05)$ yang berarti ada pengaruh kontrasepsi suntik 3 bulan terhadap kenaikan berat badan ibu di Puskesmas Gedong Air Bandar Lampung tahun 2020.

suntikan 150 mg DMPA, ovulasi tidak akan terjadi untuk minimal 14 minggu (Pinem, 2009).

Menurut pendapat peneliti KB suntik yang digunakan untuk tujuan kontrasepsi parenteral, mempunyai efek progestagen yang kuat dan sangat efektif. Dalam penggunaan jangka panjang DMPA (hingga dua tahun) turut memicu terjadinya peningkatan berat badan, kanker, kekeringan pada vagina, gangguan emosi, dan jerawat karena penggunaan hormonal yang lama dapat mengacaukan keseimbangan hormon estrogen dan progesteron dalam tubuh sehingga mengakibatkan terjadi perubahan sel yang normal menjadi tidak normal Bila sudah dua tahun, kita harus pindah ke sistem KB yang lain, seperti KB kondom, spiral, atau kalender.

\section{Peningkatan berat badan akseptor KB Suntik}

Berdasarkan hasil penelitian diketahui mean peningkatan berat badan akseptor KB Suntik 3 bulan sebesar 3,70 $\mathrm{Kg}$ dengan peningkatan berat badan minimal $0,00 \mathrm{Kg}$ dan maximal $9,00 \mathrm{Kg}$ dan dari penelitian juga diketahui mean peningkatan berat badan akseptor KB Suntik 1 bulan seberat $1,80 \mathrm{Kg}$ dengan peningkatan berat badan minimal 0,00 $\mathrm{Kg}$ dan maximal 9,00 $\mathrm{Kg}$

KB suntik yang digunakan untuk tujuan kontrasepsi parenteral, mempunyai efek progestagen yang kuat dan sangat efektif. Dalam penggunaan jangka panjang DMPA (hingga dua tahun) turut memicu terjadinya peningkatan berat badan, kanker, kekeringan pada vagina, gangguan emosi, dan jerawat karena penggunaan hormonal yang lama dapat 
mengacaukan keseimbangan hormon estrogen dan progesteron dalam tubuh sehingga mengakibatkan terjadi perubahan sel yang normal menjadi tidak normal Bila sudah dua tahun, kita harus pindah ke sistem KB yang lain, seperti KB kondom, spiral, atau kalender (Affandi, 2012).

Kontrasepsi suntik 3 bulan lebih mempengaruhi pada peningkatan berat badan karena DMPA merangsang pusat pengendalian nafsu makan hipotalamus merangsang pusat pengendalian nafsu makan di hipotalamus yang dapat menyebabkan akseptor makan lebih banyak dari biasanya, sehingga berpotensi mengalami peningkatan berat badan. Kenaikan BB, disebabkan karena hormon progesteron mempermudah perubahan karbohidrat dan gula menjadi lemak, sehingga lemak di bawah kulit bertambah, selain itu hormon progesteron juga menyebabkan nafsu makan bertambah dan menurunkan aktivitas fisik, akibatnya pemakaian suntikan dapat menyebabkan BB bertambah (Sumantri, 2018).

Lama pemakaian alat kontrasepsi hormonal berhubungan dengan risiko kegemukan (Sriwahyuni, 2012). Pada pemakaian kontrasepsi hormonal lebih dari satu tahun risiko kegemukan meningkat 1,36 kali. Kegemukan merupakan salah satu masalah gizi yang banyak terjadi dan memerlukan penanganan yang serius. Pemantauan terhadap berat badan diperlukan untuk mengetahui perubahan status gizi dan masalah kesehatan yang terjadi. Pengendalian berat badan dapat dikatakan berhasil jika seseorang dapat mencapai berat badan yang dianggap ideal untuk orang seusianya. Berdasarkan berat badan ideal inilah dapat diketahui bagaimana status gizi dan tingkat kesehatan seseorang (Sriwahyuni, 2012).

\section{Pembahasan Bivariat}

Distribusi rerata Kenaikan Berat Badan Ibu suntik 3 bulan seberat 3,70
$\mathrm{Kg}$ dan rata-rata berat badan akseptor KB suntik 1 bulan seberat $1,80 \mathrm{Kg}$, hasil uji statistik didapatkan $p$-value $=0,016$ ( $<$ a 0,05$)$ yang berarti ada pengaruh kontrasepsi suntik 3 bulan terhadap kenaikan berat badan ibu di Puskesmas Gedong Air Bandar Lampung tahun 2020.

Pada saat pemilihan alat kontrasepsi wanita harus diberikan informasi bahwa dengan memakai suntikan 3 bulan, akan mengalami perdarahan tidak teratur atau terjadi gangguan menstruasi pada penggunaan tahun pertama dan terjadi amenorea untuk jangka panjang agar wanita dapat lebih menerima hal tersebut (Arum, 2019). Karena pada kontrasepsi suntik yang berisi progestin, mempunyai efek samping yaitu pola perdarahan yang tidak teratur, episode perdarahan yang panjang, adanya bercak-bercak, dan amenorea, dengan lama pemakaian 12 bulan atau lebih penggunaan (Kusmiran, 2011). Penggunaan kontrasepsi suntik yang berisi progestin, yang jangka pemakaian 3 s.d $<12$ bulan terjadi ketiadaan menstruasi dalam waktu yang singkat (kurang 3 bulan) dinamakan delayed menses (tertundanya menstruasi) terjadinya penundaan menstruasi dalam kurun waktu kurang 3 bulan karena hal ini efek samping dari hormon yang terdapat di kontrasepsi suntik yang berisi progestin dan hormon yang terdapat pada tubuh setiap wanita adalah berbeda-beda kadarnya. Perubahan berat badan dapat mengurangi menstruasi. penurunan berat badan yang akut dapat menyebabkan gangguan pada fungsi ovarium (Mulyani, 2013).

Efek samping adalah dampak dari obat-obatan yang tidak diinginkan. Menurut Kamus Besar Bahasa Indonesia efek samping adalah akibat atau gejala yang timbul secara tidak langsung disamping proses utamanya. Efek samping Depo Medroxyprogesterone Acetate (DMPA) adalah dampak dari DMPA yang tidak diinginkan. Kontrasepsi 
suntik depo provera mengandung Depo Medroxyprogesteron Acetate (DMPA) 150 mg yang hanya berisi hormon progesterone dan tidak mengandung hormon estrogen (Arum, 2019).

Kontrasepsi suntik 3 bulan lebih mempengaruhi pada peningkatan berat badan karena DMPA merangsang pusat pengendalian nafsu makan hipotalamus merangsang pusat pengendalian nafsu makan di hipotalamus yang dapat menyebabkan akseptor makan lebih banyak dari biasanya, sehingga berpotensi mengalami peningkatan berat badan. Kenaikan BB, disebabkan karena hormon progesteron mempermudah perubahan karbohidrat dan gula menjadi lemak, sehingga lemak di bawah kulit bertambah, selain itu hormon progesteron juga menyebabkan nafsu makan bertambah dan menurunkan aktivitas fisik, akibatnya pemakaian suntikan dapat menyebabkan BB bertambah (Sumantri, 2018).

Hasil penelitian diketahui mean peningkatan berat badan akseptor $\mathrm{KB}$ Suntik 3 bulan seberat $3,70 \mathrm{Kg}$ dengan peningkatan berat badan minimal $0,00 \mathrm{Kg}$ dan maximal 9,00 $\mathrm{Kg}$ dan dari penelitian juga diketahui mean peningkatan berat badan akseptor KB Suntik 1 bulan seberat $1,80 \mathrm{Kg}$ dengan peningkatan berat badan minimal $0,00 \mathrm{Kg}$ dan maximal 9,00 $\mathrm{Kg}$.

Penelitian ini sejalan dengan teori dalam penelitian Rilyani (2018) yang mengatakan bahwa kenaikan berat badan pengguna alat kontrasepsi suntik lebih banyak dibandingkan dengan pengguna alat kontrasepsi pil. Menurut pendapat para ahli bahwa DMPA (Depot Medroxy Progesteron Asetat) merangsang pusat pengendali nafsu makan di hypothalamus yang menyebabkan akseptor makan lebih banyak dari biasanya. Karbohidrat yang dikonsumsi dalam jumlah banyak oleh hormon progesteron dirubah menjadi lemak sehingga terjadi penumpukan lemak yang menyebabkan berat badan bertambah
Menurut Rosmadewi

(2015)

kenaikan berat badan ibu selama menggunakan alat kontrasepsi hormonal antara 1-2 kg pada awal penggunaan alat kontrasepsi. Kenaikan berat badan tersebut masih dianggap normal, karena pertambahan berat badan disebabkan oleh retensi cairan, bertambahnya lemak pada tubuh, dan meningkatkan selera makan. Apabila peningkatan berat badan akseptor melebihi dari $2 \mathrm{~kg}$ selama menggunakan alat kontrasepsi hormonal perlu mendapatkan perhatian.

Berdasarkan hasil penelitian Purnamasari (2016), bahwa ada hubungan lama pemakaian KB suntik DMPA dengan perubahan berat badan dengan $\rho$ hitung $(0,587)$ lebih besar dari $\rho$ tabel $(0,364)$. Dampak yang sering timbul pada ibu-ibu dengan peningkatan berat badan ini yaitu masalah psikologi berupa gangguan terhadap citra tubuh sehingga ibu-ibu cenderung rendah diri dan kurang percaya diri terhadap lingkungan (body image).

Hasil penelitian terdapat peningkatan berat badan pada responden kelompok akseptor KB 3 bulan memiliki peningkatan berat badan sebanyak 18 responden dengan peningkatan tertinggi sebesar $9 \mathrm{Kg}$ dan pada akseptor KB suntik 1 bulan di dapatkan 13 responden dari 20 responden memiliki kenaikan berat badan dengan peningkatan terbanyak sebesar $8 \mathrm{Kg}$.

Berdasarkan hasil penelitian diketahui bahwa usia terbanyak pada akseptor KB 3 bulan dan akseptor KB 1 bulan, adalah usia reproduksi dengan kategori tidak berisiko yaitu 20-35 tahun hal ini sejalan dengan teori yang mengungkapkan bahwa usia 20-35 tahun merupakan usia yang baik dalam bereproduksi, namun harus tetap memperhatikan kondisi kesehatan sehingga diperlukan upaya untuk menjarangkan kehamilan salah satunya dengan menggunakan kontrasepsi. kontrasepsi yang digunakan dapat bermanfaat untuk mengatur jarak 
kelahiran anak walaupun tidak terlepas dari adanya dampak penggunaan kontrasepsi salah satunya adalah peningkatan berat badan, namun permasalahan berat badan dapat diantisipasi dengan mengatur konsumsi makan harian, melakukan olahraga rutin setiap hari sehingga berat badan dapat terkontrol dengan baik.

Pendidikan terbanyak pada akseptor KB 3 bulan adalah Pendidikan SMA yaitu sebanyak $10(50 \%)$, orang dan 10 $(50 \%)$, responden pada akseptor KB 1 bulan, sejalan dengan teori yang mengungkapkan bahwa pendidikan dapat mempengaruhi pengetahuan seseorang dalam hal ini adalah penggunaan kontrasepsi, dengan pendidikan yang menengah, petugas kesehatan lebih mudah untuk memberikan edukasi terkait dengan penggunaan kontrasepsi bagi ibu

Berdasarkan hasil penelitian diketahui bahwa Pekerjaan terbanyak adalah IRT pada akseptor KB 3 bulan sebanyak $16(80 \%)$ orang dan sebanyak $16(80 \%)$ responden pada akseptor KB 1 bulan, dapat diambil kesimpulan bahwa responden banyak menghabiskan waktu di rumah sehingga ada yang mengalami peningkatan yang cukup banyak kemungkinan kurangnya aktivitas fisik yang dilakukan atau banyaknya konsumsi makanan yang dimakan sehingga responden mengalami peningkatan berat badan

Penelitian ini sejalan dengan

penelitian Rosniawati (2018) Hasil penelitian menunjukkan Akseptor KB Suntik 1 bulan (Cyclofem) di Polindes Huko-Huko Kecamatan Pomalaa Kabupaten Kolaka sebagian besar tidak mengalami peningkatan berat badan sebanyak 21 orang (72,6\%). Akseptor KB Suntik 3 bulan (Depo Medroksi Progesteron Asetat/DMPA) di Polindes Huko-Huko Kecamatan Pomalaa Kabupaten Kolaka sebagian besar mengalami peningkatan berat badan sebanyak 20 orang (69,0\%).Ada perbedaan peningkatan berat badan antara akseptor KB Suntik 1 bulan (Cyclofem) dengan akseptor KB Suntik 3 bulan(Depo Medroksi Progesteron Asetat/DMPA) di Polindes Huko-Huko Kecamatan Pomalaa Kabupaten Kolaka $(p=0,003)$. Rata-rata peningkatan berat badan pada akseptor KB suntik 1 bulan adalah $1,1 \mathrm{~kg}$ (mean=1,10 $\pm 1,86$ ) dan pada akseptor KB suntik 3 bulan adalah $2,8 \mathrm{~kg}$ (mean $=2,83 \pm 2,00)$.

Hasil penelitian, diketahui bahwa kandungan dari suntik 3 bulan dan 1 bulan adalah mengandung hormon progestin, sehingga efek samping yang akan diberikan adalah sama yaitu kenaikan berat badan, kenaikan berat badan setiap wanita akan relatif berbeda dikarenakan berbagai faktor, kondisi berat badan wanita setelah pemakaian kontrasepsi hormonal suntik satu dan tiga bulan sangat bervariasi. Wanita yang mengalami peningkatan berat badan setelah pemakaian kontrasepsi hormonal suntik dapat disebabkan oleh faktor gaya hidup yaitu kebiasaan konsumsi, aktivitas fisik dan perilaku sedentari. Karena latar belakang tersebut, peneliti melakukan penelitian mengenai pengaruh gaya hidup terhadap perubahan IMT pada wanita yang menggunakan kontrasepsi hormonal suntik.

\section{KESIMPULAN}

Berdasarkan hasil penelitian dan pembahasan diketahui mean peningkatan berat badan akseptor KB Suntik 3 bulan sebesar $3,7 \mathrm{Kg}$ dengan peningkatan berat badan minimal $0 \mathrm{Kg}$ dan maximal 9,0 $\mathrm{Kg}$. Diketahui mean peningkatan berat badan akseptor KB Suntik 1 bulan seberat $1,8 \mathrm{Kg}$ dengan peningkatan berat badan minimal $0 \mathrm{Kg}$ dan maximal $8,0 \mathrm{Kg}$. Ada Pengaruh Kontrasepsi Suntik 3 Bulan Terhadap Kenaikan Berat Badan Ibu Di Puskesmas Gedong Air Bandar Lampung Tahun 2020, hasil uji statistik didapatkan $p$ value $=0,016(p$-value $>a=0,05)$

\section{SARAN}


Bagi tenaga kesehatan diharapkan dapat memberikan konseling pada akseptor kontrasepsi hormonal khususnya suntik untuk bisa beralih ke kontrasepsi non hormonal jangka panjang seperti IUD. Memberikan penyuluhan terkait dengan keuntungan dan kerugian dari penggunaan kontrasepsi hormonal, dengan menggunakan media leaflet.Dapat mengubah kontrasepsi yang digunakan yaitu kontrasepsi suntik 3 bulan, ke kontrasepsi non hormonal seperti IUD. Mengikuti penyuluhan yang .dilakukan oleh petugas kesehatan. Hasil penelitian ini dapat digunakan sebagai referensi untuk melakukan penelitian yang serupa, ataupun mengembangkan penelitian serupa dengan menambah variabel baru sehingga dapat meningkatkan kualitas akseptor kontrasepsi.

\section{DAFTAR PUSTAKA}

Affandi, Biran dkk. (2012). Buku Panduan Praktis Pelayanan Kontrasepsi. Jakarta: Penerbit Yayasan Bina Pustaka Sarwono.

Arum, D. N. S. (2019). Panduan lengkap pelayanan KB terkini. Medical Book: Jakarta

BKKBN. (2017). Jumlah Peserta KB aktif. Jakarta: BKKBN.

Dinkes. Prov. Lampung. (2016). Profil Kesehatan Lampung tahun 2015. Bandar Lampung: Dinkes Prov. Lampung, 2016

Hartanto, H. (2004). Keluarga berencana dan kontrasepsi.

Kementerian Kesehatan Republik Indonesia. (2017). Profil kesehatan Indonesia tahun 2016. Jakarta: Depkes RI.

Kusmiran, E. (2011). Kesehatan Reproduksi Remaja Dan Wanita (J. Selatan, Ed.). Jakarta: Salemba Medika.

Manuaba, I. B. G. (2014). IImu Kebidanan, Penyakit Kandungan dan KB untuk Pendidikan Bidan (Edisi 2). Jakarta: EGC, 421-424.
Mulyani, N. S. M. D. K. (2013). Keluarga Berencana dan Alat Kontrasepsi. Nuha Medika: Persada 1, 2.

Panjaitan. B. (2017). Hubungan Antara Jenis Kontrasepsi Suntik Dan Lama Pemakaian Dengan Kenaikan Berat Badan Pada Akseptor Kb. Jurnal Kesehatan Metro Sai Wawai.

Pinem, S. (2009). Kesehatan reproduksi dan kontrasepsi. Jakarta: TIM.

Pratiwi , D. dkk. (2014). Hubungan Antara Penggunaan Kontrasepsi Hormonal Suntik DMPA dengan Peningkatan Berat Badan di Puskesmas Lapai Kota Padang. Jurnal Kesehatan Andalas.

Purnamasari, D. (2009). Hubungan Lama Pemakaian Kb Suntik Depo Medroksi Progesteron Asetat (Dmpa) Dengan Perubahan Berat Badan Di Bps (Bidan Praktek Swasta) "Yossi Trihana" Jogonalan Klaten. [Tesis]. Surakarta: Universitas Sebelas Maret.

Puskesmas Gedong Air. (2020). Data Puskesmas Gedong Air.

Rahayu, S. 2018. Efek Samping Kontrasepsi Suntik Cyclofem Dan DMPA. Jurnal Stikkes Aisiyah Palembang 9 (3).

Rilyani, Deni M, Minawati. (2018). Hubungan Penggunaan Kontrasepsi Suntik Dengan Gangguan Menstruasi Di Wilayah Kerja Puskesmas Kotabumi II Kabupaten Lampung Utara Tahun 2018. Holistik Jurnal Kesehatan 12 (3).

Rosmadewi. (2015). Perbedaan Kenaikan Berat Badan Wanita Usia Subur Antara Pengguna Alat Kontrasepsi Pil Dan Suntik. Jurnal Ilmiah Keperawatan Sai Betik.

Rosniawati, Kartini, Melania A. (2018). Perbedaan Peningkatan Berat Badan Antara Akseptor Kb Suntik 1 Bulan (Cyclofem) Dengan Akseptor Kb Suntik 3 Bulan(Depo Medroksi Progesteron Asetat/Dmpa) Di Polindes Huko-Huko Kecamatan Pomalaa Kabupaten Kolaka. Poltekkes Kemenkes Kendari. 
[Skripsi]. Kendari: Poltekkes Kendari.

Roza, E \& Zita, A. (2017). Hubungan penggunaan kontrasepsi suntik DMPA dengan peningkatan berat badan pada akseptor di Puskesmas Tapus Sumatera Barat tahun 2017. Tarumanegara Medical Journal 2 (1).

Saifuddin, AB. (2014). Panduan Praktis Pelayanan Kesehatan Maternal dan Neonatal. Jakarta: EGC.

Sriwahyuni, E., \& Wahyuni, C. U. (2012). Hubungan antara jenis dan lama pemakaian alat kontrasepsi hormonal dengan peningkatan berat badan akseptor. Public Health 8 (3).

Sumantri, AW. (2018). Hubungan Suntikan Kb 3 Bulan Dengan

Kenaikan Berat Badan Di Desa Laya Wilayah Kerja Uptd Puskesmas Tanjung Agung Kecamatan Baturaja Barat Tahun 2018. Babul Ilmi Jurnal Ilmiah Multi Science Kesehatan 8. 